\section{Mast Cell Stabilizers as a Supportive Therapy Can Contribute to Alleviate Fatal Inflammatory Responses and Severity of Pulmonary Complications in COVID-19 Infection}

\author{
Destekleyici Bir Tedavi Olarak Mast Hücre \\ Stabilizatörleri COVID-19 Enfeksiyonunda Ölümcül \\ Inflamatuar Yanıtları ve Pulmoner Komplikasyonların \\ Siddetini Hafifletmeye Katkıda Bulunabilir
}

\begin{abstract}
SARS-CoV-2(COVID-19) leads to severe acute respiratory syndrome by settling the pulmonary system. Mast cells (MCs) are multifunctional immune cells that are extensively distributed throughout the body and mostly present in pulmonary system.

MCs play a vital role in acquired and innate immunity, and to maintain immune homeostasis of the body through a wide range of mediators in their cytoplasmic granules. Severe acute respiratory syndrome with proinflammatory cytokine release and pneumonia during COVID-19 infection can result in the death, in particular in debilitated individuals or those suffering from related chronic disorders. In this review, we attempt to discuss potential relationship between COVID-19 symptoms and mast cells as well as potential use of mast cell stabilizers as a supportive therapeutic option in COVID-19 infection.

MCs are main source of pro-inflammatory cytokines such as IL-1, IL-6 and TNF-a as well as bronchoconstrictor mediators such as histamine, prostaglandin-D2 and leukotriene-C4 that can lead to fatal inflammatory responses and pulmonary complications during COVID-19 infection. SARS-CoV-2 may activate MCs through toll-like receptors or by inducing the crosslinking of the $\operatorname{lgE}-\mathrm{FC}_{\varepsilon} \mathrm{RI}$, thus leading to release of those mediators. SARS-CoV-2-induced abnormal production and release of these mediators from MCs can further exacerbate inflammation in respiratory system, consequently pulmonary complications.

Therefore administration of MC stabilizers as a supportive therapy may be useful to alleviate inflammatory responses and pulmonary complications in order to reduce deaths from SARSCoV-2 infection.
\end{abstract}

Keywords: SARS-CoV-2; COVID-19; mast cells; inflammatory mediators; mast cell stabilizers.

\section{Öz}

SARS-CoV-2 (COVID-19) pulmoner sisteme yerleșerek ciddi akut solunum yetmezliği sendromuna yol açmaktadır. Mast hücreleri vücutta yaygın dağılım gösteren ve pulmoner sistemde bol miktarda bulunan çok fonksiyonlu bağıșıklık hücreleridir. Mast hücreleri doğal ve kazanılmış bağışıkıkta ve vücudun bağışıkık homeostazının sürdürülmesinde sitoplazmik granüllerindeki çeșitli mediyatörler aracılığıyla hayati bir rol oynamaktadır. COVID-19 enfeksiyonu sırasında pro-inflamatuar sitokin salınımı ve pnömoni ile karakterize ağır akut solunum yetmezliği özellikle zayıf veya ilișkili kronik hastalıklardan muzdarip bireylerde ölümle sonuçlanabilmektedir. Bu derlemede COVID-19 semptomları ve mast hücreleri arasındaki potansiyel ilișkiyi ve destekleyici bir terapötik seçenek olarak mast hücre stabilizatörlerinin COVID-19 enfeksiyonunda potansiyel kullanımını tartıșmaya çalıștık.

Mast hücreleri, COVID-19 enfeksiyonu sırasında ölümcül inflamatuar yanıtları ve pulmoner komplikasyonları tetikleyebilen IL-1, IL-6 ve TNF-a gibi pro-inflamatuar sitokinlerin ve histamin,
Erkan Kilinc ${ }^{1}$,

Yasemin Baranoglu Kilinc ${ }^{2}$

Bolu Abant Izzet Baysal University, Faculty of Medicine, Department of Physiology

2 Bolu Abant İzzet Baysal University, Faculty of Medicine, Department of Pediatrics

Received/Gelis : 14.04.2020 Accepted/Kabul : 19.04,2020

DOI: 10.21673/anadoluklin.720116

Corresponding author/Yazışma yazarı Erkan Kılınc

Bolu Abant Izzet Baysal Üniversitesi, Tıp Fakültesi, Fizyoloji Anabilim Dalı E-mail: erkankilinc27@gmail.com

\section{ORCID}

Erkan KIIınç: 0000-0001-9261-2634 Yasemin B. KIlınç: 0000-0002-1795-5677 
prostaglandin-D2 ve lökotrien-C4 gibi bronkokonstriktör mediyatörlerin ana kaynağıdır. SARS-CoV-2, mast hücrelerini toll-like reseptörleri aracılığıyla veya IgE-FC\&RI'nın çapraz bağlanmasını tetikleyerek aktive edebilir ve böylece mast hücrelerinden bu mediyatörlerin salınımına yol açar.

Mast hücrelerinden bu mediyatörlerin SARS-CoV-2 ile tetikIenmiş anormal üretimi ve salınımı solunum sisteminde inflamasyonu ve sonuçta pulmoner komplikasyonları daha fazla kötüleștirebilir. Böylece destekleyici bir tedavi olarak mast hücre stabilizatörlerinin kullanılması SARS-CoV-2 enfeksiyonundan ölümleri azaltmak amacıyla inflamatuar yanıtları ve pulmoner komplikasyonları hafifletmek/iyileștirmek için faydalı olabilir.

Anahtar Sözcükler: SARS-CoV-2; COVID-19; mast hücreleri; inflamatuar mediyatörler; mast hücre stabilizatörleri.

\section{Background}

Outbreak of severe acute respiratory syndrome coronavirus-2 (SARS-CoV-2) or novel coronavirus (2019-nCoV) continues to cause the deaths worldwide (1). As of April 12, 2020, a total of 1.696588 confirmed cases and 105952 deaths have been announced by the World Health Organization (2). Coronaviruses are enveloped RNA viruses and widely permeated among humans, other mammals, and birds (3). Coronaviruses lead to respiratory, enteric, hepatic, and neurologic diseases (4). SARS-CoV-2 belongs to the genus Coronaviruses. COVID-19, which is now rapidly spreading and becoming a pandemic, has been first identified and isolated from patients with pneumonia in Wuhan, China (3). It causes principally a severe acute respiratory disease.

\section{Transmission}

It is considered that the virus was first transmitted most probably from animal to human on the Huanan seafood market in Wuhan, China. Notwithstanding COVID-19 is speculated to be originated from bats, its certain resource, animal reservoir and enzootic patterns of transmission are not yet accurately known (5). However, increases in the number of cases worldwide demonstrate frankly that COVID-19 is also transmitted from human to human. It is known that transmission of the virus from human to human occurs principally through respiratory tract, by droplets, respiratory secretions, and direct contact with an infected person who has the viral symptoms including cough and sneezing (6). When anybody inhales air borne droplets from infected person, the virus arrive at the respiratory tracts and the lungs. But until now, it has not been reported that whether a person who touched the infected surfaces or objects will be infected by CO-

VID- 19. However, after the transmission, the virus enters ciliated epithelium in the respiratory system. Although not yet certain, it is postulated that the virus may probably enter to cells in the ciliated epithelium by using angiotensin converting enzyme 2 (4). Then the virus is replicated in such cells and leads to cellular damage and infection at infection site.

\section{Diagnostic criteria}

It has been reported that until now the securest clinical diagnosis method for COVID-19 is to detect nucleic acid (RNA) of the virus in the swab samples of nose and throat, or the other respiratory tract samples such as bronchoalvelor lavage fluid by real-time polymerase chain reaction (6).

\section{Clinical symptoms}

It has been reported that the most common symptoms of COVID-19 infection include fever, cough, fatigue, sputum production, dyspnoea, sore throat, haemoptysis, diarrhoea, lymphopenia as well as headache $(4,6)$. Fever and cough from those common symptoms are mostly seen, on the contrary upper respiratory symptoms and gastrointestinal symptoms are reported as scarce $(6,7)$. In addition to pneumonia, acute respiratory distress syndrome, septic shock, metabolic acidosis and even the death can occur specially in elderly individuals and patients who have one of such disorders such as hypertension, chronic obstructive pulmonary disease, diabetes, cardiovascular disease $(6,8)$.

\section{Treatment}

Currently almost all of the world suffers from COVID-19 outbreak and pneumonia caused by it, and the number of COVID-19 positive cases and deaths are rapidly increasing day by day worldwide. Unfortunately, a special vaccine for COVID-19 has not yet been developed although the scientists have worked 
hard to achieve this. However, the physicians have administered only supportive therapies such as use of antipyretic agents, maintenance of hydration, mechanical ventilation for respiratory support and use of antibiotic in bacterial infections to ameliorate the clinical symptoms (4). Therefore supportive therapies are of vital importance to struggle against life-threatening symptoms of COVID-19 such as pneumonia, severe acute respiratory distress syndrome, septic shock and metabolic acidosis.

\section{Mast cells}

Mast cells (MCs) are multifunctional immune cells originating from $\mathrm{CD} 34+/ \mathrm{CD} 117+$ myeloid progenitor cells in the bone marrow (9). MCs are extensively distributed throughout the body and present in mucosal and connective tissues. MCs participate in a great variety of physiological and pathophysiological conditions such as innate and adaptive immunity, inflammation, allergies, asthma, eczema, interstitial cystitis, irritable bowel syndrome, migraine and pulmonary hypertension (10-13). When activated, MCs release a wide range of the pre-formed and de novo synthesized mediators mediating those physiological and pathophysiological situations through their degranulation $(14,15)$. MCs store a large number of vasoactive and pro-inflammatory mediators, proteases, cytokines, chemokines, and growth factors such as substance P (SP), serotonin, prostaglandins, bradykinin, histamine, tumor necrosis factor- $\alpha$ (TNF- $\alpha$ ) interleukin (IL)- $1 \beta$, granulocyte-macrophage colony stimulating factor etc in their cytoplasmic granules (16-18). MCs can be activated by immunologic and non-immunologic stimuli such as IgE, antigens, anaphylatoxins, viruses, bacteria, toxins, detergents, food additives/ preservatives, xenoestrogens, neuropeptides, cold, exercise, radiation and pollutants $(19,20)$. While mild activation of MCs under physiological conditions is needed to maintain homeostasis of body systems, their overactivation causes immunological disorders mentioned above. Therefore, stabilization of MCs are of vital importance to treat MC activation-related disorders and to ameliorate symptoms caused by immunological reactions. Life-threatening immunological processes following pathologi- cal stimuli such as COVID-19 can be restrained using endogenous and exogenous mast cell stabilizing agents.

\section{Mast cell activators and mechanisms of mast cell activation}

MCs can be activated in immunoglobulin E (IgE)dependent and IgE-independent manners. Mature B-cells generate IgE antibodies in response to CD4+ Th2 cells (21). MCs express Fc $\in$ RI receptors on the cell surface. IgE is mostly present bound to the high-affinity receptors, $\mathrm{Fc} \in \mathrm{RI}$, on $\mathrm{MCs}(9,22)$. When an antigen entering the body through virus or the other sources comes into contact with MCs, MCs are activated by cross-linking of the IgE-FceRI, and release contents of the granules to their resident environments $(9,22)$. $\operatorname{IgE}$ is present in the respiratory tract, connective tissue under epithelial layers of the skin, as well as in the gastrointestinal tract (21). Additionally, MCs express different receptors including Fc receptors, toll-like receptors (TLR), as well as receptors for chemokines, cytokines, and pathogen-associated molecular patterns which are related to $\mathrm{MC}$ activation and immune responses $(21,22)$. Particularly TLR is expressed both on the cell membrane and in the cytosol of MCs and able to recognise viruses, bacteria and fungi.

Moreover, some hormones and neuropeptides including corticotropin-releasing hormone, substance $\mathrm{P}$, calcitonin gene-related peptide and neurotensin are capable of stimulating the activation of MCs through G-protein coupled receptors in the cell membrane of MCs $(23,24)$. In addition, it was reported that pituitary adenylate cyclase activating peptide-38 evoked rat peritoneal and dural MCs degranulation through the phospholipase-C pathway (25). Cytokines including stem cell factor (SCF), IL-3, IL-4, IL-9, IL-33 are able to activate MCs (23). Histamine from MCs can cause degranulation of human MCs via H4R receptor (26). It was stated that several chemokines such as CXCL12 and CCL11 can selectively stimulate mediator release from MCs (27). In addition to the above, there are also more endogenous MC triggers such as insulin-like growth factor-1, stem cell factor, leptin, acetylcholine, estrogen, $\beta$-endorphin, nitric oxide etc. (28). 
Figure 1. Hypothetical illustration for potential mechanisms of SARS-CoV-2-induced mast cell activation and alleviation of the symptoms by mast cell stabilizers

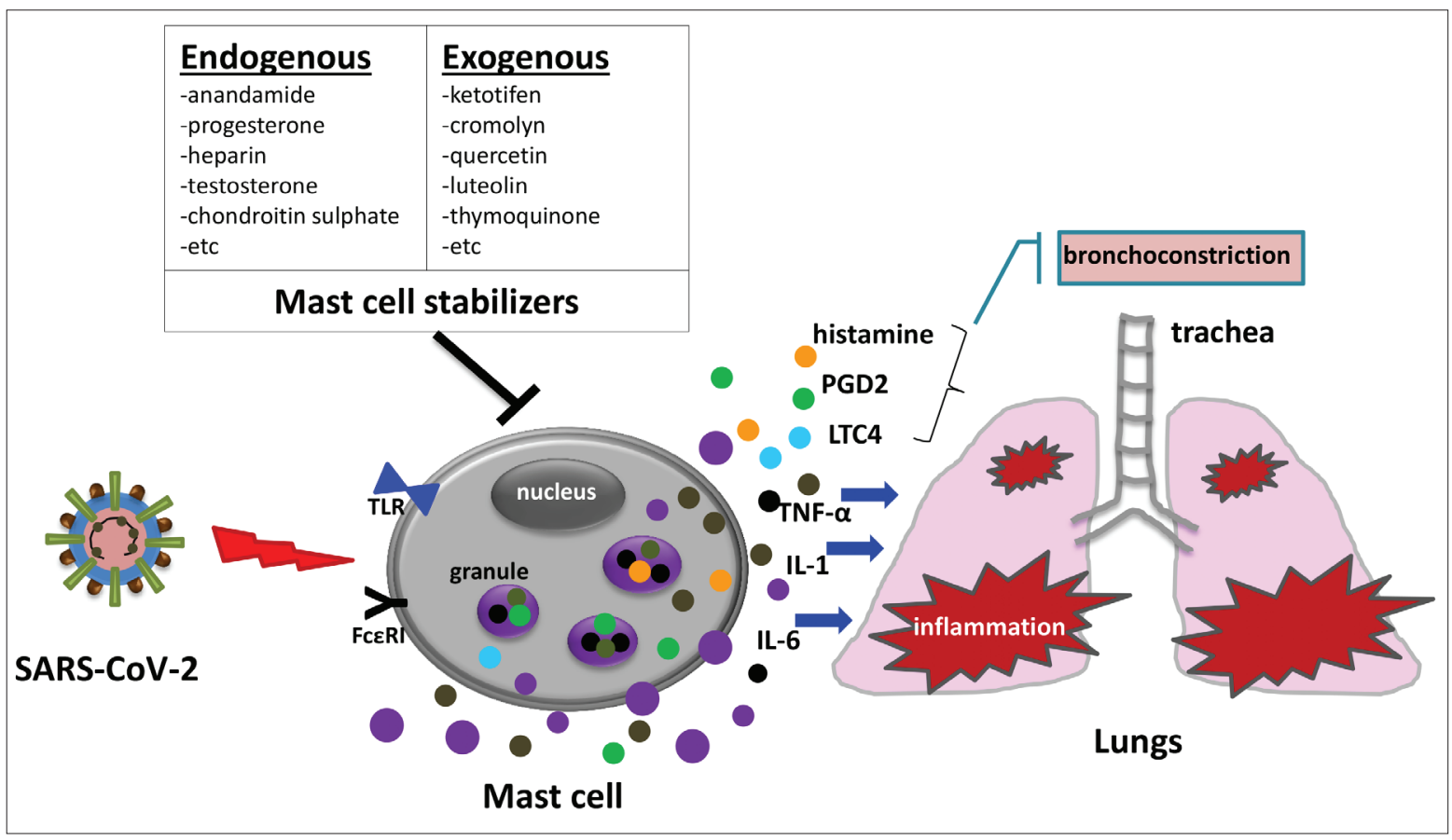

SARS-CoV-2 may activate mast cells in the respiratory system through toll-like receptors or by inducing the cross-linking of the IgE-FceRI. Activated mast cells release pro-inflammatory cytokines such as IL-1, IL-6 and TNF- $\alpha$ as well as bronchoconstrictor mediators such as histamine, prostaglandin-D2 and leukotriene-C4. Abnormal production and release of these mediators from mast cells can further exacerbate SARS-CoV-2-induced inflammation in the respiratory system. Therefore endogenous or exogenous stabilizers of mast cells may alleviate inflammatory responses and pulmonary complications by suppressing activation of mast cells in SARS-CoV-2 infection. TLR: toll-like receptor, TNF- $\alpha$ : tumor necrosis factor- $\alpha$, IL: interleukin, LTC4: leukotriene-C4, PGD2: prostaglandin-D2.

\section{Mast cell stabilizers}

Mediators from MCs are involved in a wide range of conditions such as itching, allergies, conjunctivitis, asthma, mastocytosis, pain, and neurodegenerative disorders. Therefore, MC stabilizers are of vital importance in the prophylaxis and treatment of mast cell activation-mediated disorders. MC stabilizers can be categorized primarily as endogenous and exogenous mast cell stabilizing agents.

\section{Endogenous stabilizers of mast cells}

MCs perform their physiological functions in the body by balancing between degranulation and stabilization conditions. By balancing degranulation/ stabilization of MCs, endogenous stabilizers of MCs play a vital role in controlling activation of MCs and consequently in the immune homeostasis of the body. It was demonstrated that heparin and chondroitin sulphate from MCs are able to inhibit the activation of MCs (29). Spermine in MC granules was shown to prevent MC secretion in rats (30). Moreover, progesterone and testosterone from sex hormones show inhibitory effects on the MC activation $(31,32)$. It was reported that beta receptor agonists blocked MC activation by inhibiting release of mediators such as histamine, TNF- $\alpha$ and prostaglandin D2 $(33,34)$. Additionally, there are different endogenous molecules which are able to inhibit degranulation of MCs such as corticosterone, cortisone (28), anandamide, 2 -arachidonoyl glycerol (2-AG) $(35,36)$.

\section{Exogenous stabilizers of mast cells}

In addition to endogenous stabilizers of mast cells, there are also present various exogenous stabilizers of MCs including synthetic (e.g. ketotifen), semi-synthetic (e.g. indanone and pterosin Z), and plant-derived mast cell stabilizers (e.g. cromolyn, quercetin and luteolin). Cromolyn sodium is prominent drug of such MC stabilizers. It is used in treating MC-related disorders such as asthma, 
allergic rhinitis, allergic conjunctivitis, and mastocytosis (37). In addition, ketotifen is another mast cell stabilizer however it has also antagonistic effect for histamine-1 receptor (38). Spleen tyrosine kinase (Syk) inhibitors like compound-13, R-112 and ER-27317 are synthetic inhibitors of MCs that are able to inhibit the signal transduction of the allergic reactions such as asthma, anaphylaxis and allergic rhinitis (39). Another chemical group of MC stabilizers is JAK3 inhibitors that prevent activation of MCs by inhibiting JAK3 signaling pathway (40). Additionally, kit tyrosine kinase inhibitors are also an important group of chemical stabilizers of MCs (38). It was shown that hypothemycin blocked FceRI-mediated activation of MCs and also cytokine production from MCs by inhibiting Kit kinase activity (41). Moreover, inhibitors of phosphodiesterases are considered to be chemical stabilizers of MCs due to the fact that they inhibit the activation of MCs (42). Recently, there is an emerging interest to plant-derived mast cell stabilizers, quercetin and luteolin. Because it was demonstrated that quercetin and luteolin have potent inhibitor effect against human mast cells. Apart from these, We have previously showed that a synthetic peptide salmon calcitonin suppressed glyceryltrinitrate(a nitric oxide donor)-induced activation of meningeal MCs (18). In addition to this, we have recently demonstrated that phytochemical agent thymoquinone inhibited the degranulation of meningeal MCs induced by glyceryltrinitrate (43).

\section{Potential relationship between COVID-19 symptoms and mast cells, and the importance of mast cell stabilizers}

Up till now, there is no yet a special vaccine or effective drug for COVID-19. Therefore supportive therapies are needed to reduce the life-threatening symptoms and consequently deaths. Prominent symptoms of COVID-19 including severe lung failure, dyspnoea, pneumonia, septic shock, and the ground-glass opacities are held responsible for most of the deaths from the infection (44).

As mentioned above, MCs contain a wide variety of vasoactive and highly inflammatory mediators, such as histamine, IL-1, IL6, TNF- $\alpha$, interferon- $\gamma$
(IFN- $\gamma$ ) and IL8(CXCL8) (16). When activated, MCs release those mediators by explosive extrusion of mediator-containing granules, which characterizes anaphylactic degranulation, or by release of granular contents a process called piecemeal degranulation (45).

TLRs expressed by MCs are able to recognise viruses, bacteria and fungi. SARS-CoV-2 may activate MCs through TLRs or by inducing the cross-linking of the IgE-FceRI, thus leading to release of those inflammatory mediators. SARS-CoV-2-induced abnormal production and release of these mediators from MCs can further exacerbate inflammation in respiratory system.

In any case, proinflammatory cytokines such as IL-1, IL6 and TNF- $\alpha$ and IL-8 are chief mediators of inflammation and fever in conditions induced by viruses, bacteria and fungi. It is clear that these mediators released as a result of activation of MCs can exacerbate inflammation in lungs during SARS-CoV-2 infection. Viral infections can evoke IL-1 release, which, in turn leads to lung and tissue inflammation, fever and fibrosis $(46,47)$. It was suggested that IL-37 can inhibit inflammation in SARS-CoV-2-induced inflammatory state by suppressing IL-1 $\beta$, IL6 and TNF due to the fact that these mediators are involved in lung inflammation, fever and fibrosis $(46,48-51)$.

Previously in a clinical study was demonstrated that plasma levels of IL-1beta were markedly increased while plasma levels of IL- 6 and TNF- $a$ were mildly raised in pediatric patients with SARSassociated coronavirus infection (52). In another study, authors showed the elevated expressions of IL- $1 \beta$, IL- 6 and TNF- $\alpha$ in the SARS-CoV-infected ACE2+cells in lung and bronchial autopsy tissues from four patients who died of SARS (53). Okabayashi and colleagues demostrated that SARSCoV evoked eleveated levels of IL-6 in SARS-CoVinfected $\mathrm{Caco} 2$ cells compared with other respiratory viruses including influenza A virus and human (54). Moreover they also showed that SARS-CoV infection evoked upregulation of TLR 4 and 9 which are associated with the initiation of inflammatory response (54). Additionally, it was stated to be a potent relationship between IL-6 peak levels and 
severity of pulmonary complications in COVID-19 infection (51).

As mentioned above, when it is considered that MCs express TLRs, we can speculate that SARSCoV-2 may lead to activation of MCs in pulmonary system which, in turn, induce immune responses. Moreover cytokines released from activated MCs such as IL-1, IL6 and TNF- $\alpha$ and IL-8 would in turn further exacerbate the inflammation state. In this state, although use of IL-1, IL- 6 and TNF- $\alpha$ blockers seems as plausible to alleviate severity of inflammation, and consequently pulmonary complications in COVID-19 infection, this may lead to weaken total immune response of the body. Moreover, it was reported that anti-TNF- $\alpha$ agents are contraindicated in SARS-CoV-2-infected subjects (51). Instead of these, use of MC stabilizing agents as a supportive therapy may be useful to alleviate inflammatory responses in order to reduce mortality.

In addition, a lot of mast cell-derived mediators such as histamine, prostaglandin (PG)D2 and leukotriene (LT)C4 have been known directly to affect airway smooth muscle function. In particular, these three mediators including histamine, PGD2 and LTC4 evoke bronchoconstriction, mucus secretion and mucosal oedema, thus making difficult breath process $(46,47,55)$. It is well known that histamine leads to the bronchoconstriction via $\mathrm{H} 1$ receptors in the respiratory system, in particular in asthma condition. Additionally, it was suggested that tryptase from MCs can also lead to bronchoconstriction in experimental studies (55). During SARS-CoV-2 infection, these potent constrictor mediators from activated MCs can endanger the life of the patients through potent bronchoconstriction of airways. Administration of endogenous or exogenous mast cell stabilizing agents during COVID-19 infection may preserve the patients against bronchoconstriction mediated damages, and also promote to fight the infection.

Pulmonary fibrosis is a condition with progressive fibrosis in lungs that may cause pulmonary dysfunction and decreased quality of life in SARS survivors after recovery. It has been suggested that pulmonary fibrosis may be one of the main complications in patients with COVID-19 infection
$(47,48,56)$. It has not been yet stated the mechanisms underlying COVID-19-induced pulmonary fibrosis, but based on the existing theoretical basis, we can speculate that mediators from SARS-CoV2-activated pulmonary MCs may contribute to this condition. Our reasoning is in line with the literature reporting $\mathrm{MC}$ mediators led to pulmonary fibrosis. Those studies reported that mediators from activated MCs are able to enhance migration and proliferation of fibroblasts in vitro (57), and MCs also enhance the fibrosis in a number of organs (58, 59). It has been proposed that the number of connective tissue mast cells is raised in inflammatory airway diseases such as asthma and chronic obstructive pulmonary disease $(60,61)$. In addition, it was stated to be an increase in chymase expression which is a connective tissue MC-derived mediator in human idiopathic interstitial pneumonia (62). Moreover, it was shown that connective tissue mast cells were increased in fibrotic areas of the alveolar parenchyma in patients with idiopathic pulmonary fibrosis (63). In a recent paper has been suggested that IL-1 induced by viral infections is also involved in pulmonary fibrosis (47). Therefore, in the context of these reports, it may be reasonable inhibition of pulmonary MCs by endogenous or chemical stabilizers of MCs in preventing pulmonary fibrosis in COVID-19 patients.

Taken together, severe pneumonia induced by human coronaviruses including SARS-CoV-2 is closely connected with rised pro-inflammatory cytokine responses resulting in acute pulmonary injury and severe acute respiratory syndrome. Mast cells are main source of pro-inflammatory cytokines and bronchoconstrictor mediators that can lead to fatal inflammatory responses and pulmonary complications during COVID-19 infection. Therefore administration of MC stabilizers may be of prime importance among existing supportive therapies. A hypothetical illustration for potential mechanisms of SARS-CoV-2-induced mast cell activation and alleviation of the symptoms by mast cell stabilizers is shown in figure 1.

Someone might argue that the immune system of the body may weaken in combating COVID-19 infection when activation of MCs are suppressed by 
MC stabilizers. However, we speculate that i) mild stabilization of MCs by MC stabilizers may be useful, ii) the other immune cells continue to produce related mediators in order to combat the infection due to immune cells of the body are not only MCs but also the other defense cells such as white blood cells, tissue macrophages, $\mathrm{T}$ and $\mathrm{B}$ cells, iii) respiratory system contains substantial amounts of MCs in the body.

In conclusion, we suggest that MC stabilizers as a supportive therapy may be a promising candidate in attenuating fatal inflammatory responses and respiratory distress in order to reduce deaths in COVID-19 infection.

\section{REFERENCES}

1. Ankaralı H, Ankaralı S, Erarslan N. COVID-19, SARSCoV2, Infection: current epidemiological analysis and modeling of disease. Anatol Clin, 2020; 25(Supplement 1): 1-22.

2. https://www.who.int/docs/default-source/coronaviruse/situation-reports/20200412-sitrep-83-covid-19. pdf?sfvrsn=697ce98d_4

3. Zhu N, Zhang D, Wang W, et al. A Novel Coronavirus from Patients with Pneumonia in China, 2019. N Engl J Med 2020;382(8):727-733. doi:10.1056/NEJMoa2001017

4. Kumar D, Malviya R, Kumar Sharma P. Corona Virus: A review of COVID-19. EJMO 2020; 4(1): 8-25.

5. Shanmugaraj B, Siriwattananon K, Wangkanont $K$, Phoolcharoen W. Perspectives on monoclonal antibody therapy as potential therapeutic intervention for Coronavirus disease-19 (COVID-19). Asian Pac J Allergy Immunol 2020;38(1):10-18.

6. Guo YR, Cao QD, Hong ZS, et al. The origin, transmission and clinical therapies on coronavirus disease 2019 (COVID-19) outbreak - an update on the status. Mil Med Res 2020;7(1):11.

7. Chan JF, Yuan S, Kok KH, et al. A familial cluster of pneumonia associated with the 2019 novel coronavirus indicating person-to-person transmission: a study of a family cluster. Lancet. 2020;395(10223):514-523. doi:10.1016/S0140-6736(20)30154-9

8. Lu H, Stratton CW, Tang YW. Outbreak of pneumonia of unknown etiology in Wuhan, China: the mystery and the miracle. J Med Virol 2020;92(4):401-402.

9. Koyuncu Irmak D, Kilinc E, Tore F. Shared fate of men- ingeal mast cells and sensory neurons in migraine. Front Cell Neurosci 2019;13:136.

10. Theoharides TC, Cochrane DE. Critical role of mast cells in inflammatory diseases and the effect of acute stress. J Neuroimmunol 2004;146(1-2):1-12.

11. Kilinc E, Dagistan Y, Kotan B, Cetinkaya A. Effects of Nigella sativa seeds and certain species of fungi extracts on number and activation of dural mast cells in rats. Physiol Int 2017;104(1):15-24. doi: 10.1556/2060.104.2017.1.8.

12. Tete S, Tripodi D, Rosati M, Conti F, Maccauro G, Saggini A, Salini V, Cianchetti E, Caraffa A, Antinolfi P, Toniato E, Castellani ML, Pandolfi F, Frydas S, Conti P, Theoharides TC. Role of mast cells in innate and adaptive immunity. J Biol Regul Homeost Agents. 2012;26(2):193201.

13. Kilinc E, Balci CN. An investigation of lung mast cell behavior in a rat model of migraine: Implications for migraine headache. Anatol Clin. 2018; 23(3): 151-156. DOI: 10.21673/anadoluklin.429905.

14. Kilinc E, Guerrero-Toro C, Zakharov A, Vitale C, Gubert-Olive M, Koroleva K, Timonina A, Luz LL, Shelukhina I, Giniatullina R, Tore F, Safronov BV, Giniatullin R. Serotonergic mechanisms of trigeminal meningeal nociception: Implications for migraine pain. Neuropharmacology 2017;116:160-173. doi:10.1016/j. neuropharm.2016.12.024.

15. Kilinc E, Firat T, Tore F, Kiyan A, Kukner A, Tuncel N. Vasoactive intestinal peptide modulates c-fos activity in the trigeminal nucleus and dura mater mast cells in sympathectomized rats. J Neurosci Res 2015;93(4):644-50.

16. Theoharides TC, Alysandratos KD, Angelidou A, et al. Mast cells and inflammation. Biochim Biophys Acta 2012;1822(1):21-33. doi:10.1016/j.bbadis.2010.12.014

17. Kilinc E, Dagistan Y, Cetinkaya A, Tore F. The comparison of effects of applications of compound 48/80 and mast cell mediator suspension on inflammation in rats: A methodological study for acute inflammatory pain. Clin Exp Health Sci 2019; 9: 34-41; - DOI: 10.5152/clinexphealthsci.2018.923

18. Kilinc E, Dagistan Y, Kukner A, et al. Salmon calcitonin ameliorates migraine pain through modulation of CGRP release and dural mast cell degranulation in rats. Clin Exp Pharmacol Physiol 2018;45(6):536-546.

19. Theoharides TC, Kempuraj D, Sant GR. Mast cell involvement in interstitial cystitis: a review of human and experimental evidence. Urology. 2001;57(6 Suppl 1):4755.

20. Moon TC, Befus AD, Kulka M. Mast cell mediators: their differential release and the secretory pathways 
involved. Front Immunol 2014;5:569. doi:10.3389/fimmu.2014.00569.

21. Krystel-Whittemore M, Dileepan KN, Wood JG. Mast Cell: A multi-functional master cell. Front Immunol 2016;6:620.

22. Tore F, Tuncel N. Mast cells: target and source of neuropeptides. Curr Pharm Des 2009;15(29):3433-3445.

23. Yu Y, Blokhuis BR, Garssen J, Redegeld FA. Non-IgE mediated mast cell activation. Eur J Pharmacol 2016;778:3343.

24. Tore F, Tuncel N. Anatomical and functional relationships between sensory nerves and mast cells. Anti-Inflammatory \& Anti-Allergy Agents in Medicinal Chemistry 2011; 10: 10-17. https://doi. org/10.2174/187152311795325550.

25. Baun M, Pedersen MH, Olesen J, Jansen-Olesen I. Dural mast cell degranulation is a putative mechanism for headache induced by PACAP-38. Cephalalgia. 2012;32(4):337-45.

26. Jemima EA, Prema A, Thangam EB. Functional characterization of histamine $\mathrm{H} 4$ receptor on human mast cells. Mol Immunol 2014;62(1):19-28.

27. Juremalm M, Nilsson G. Chemokine receptor expression by mast cells. Chem Immunol Allergy 2005;87:130-44.

28. Theoharides TC. Neuroendocrinology of mast cells: Challenges and controversies. Exp Dermatol 2017;26(9):751-759.

29. Theoharides TC, Patra P, Boucher W, Letourneau R, Kempuraj D, Chiang G, Jeudy S, Hesse L, Athanasiou A. Chondroitin sulphate inhibits connective tissue mast cells. Br J Pharmacol 2000;131(6):1039-49.

30. Vliagoftis H, Mak L, Boucher W, Theoharides TC. Dual effect of spermine on mast cell secretion exhibits different calcium and temperature requirements. Int J Immunopharmacol 1999;21(9):547-559.

31. Vasiadi M, Kempuraj D, Boucher W, Kalogeromitros D, Theoharides TC. Progesterone inhibits mast cell secretion. Int J Immunopathol Pharmacol 2006;19(4):787-94.

32. Guhl S, Artuc M, Zuberbier T, Babina M. Testosterone exerts selective anti-inflammatory effects on human skin mast cells in a cell subset dependent manner. Exp Dermatol 2012;21(11):878-80.

33. Liu WL, Boulos PB, Lau HY, Pearce FL. Mast cells from human gastric mucosa: a comparative study with lung and colonic mast cells. Agents Actions. 1991;33(1-2):13-5.

34. Okayama Y, Church MK. Comparison of the modulatory effect of ketotifen, sodium cromoglycate, procaterol and salbutamol in human skin, lung and tonsil mast cells. Int Arch Allergy Immunol 1992;97(3):216-225.
35. Sugawara K, Zákány N, Hundt T, Emelianov V, Tsuruta D, Schäfer C, Kloepper JE, Bíró T, Paus R. Cannabinoid receptor 1 controls human mucosal-type mast cell degranulation and maturation in situ. J Allergy Clin Immunol 2013;132(1):182-193.

36. De Filippis D, Luongo L, Cipriano M, et al. Palmitoylethanolamide reduces granuloma-induced hyperalgesia by modulation of mast cell activation in rats. Mol Pain 2011;7:3

37. Storms W, Kaliner MA. Cromolyn sodium: fitting an old friend into current asthma treatment. J Asthma. 2005;42(2):79-89.

38. Zhang T, Finn DF, Barlow JW, Walsh JJ. Mast cell stabilisers. Eur J Pharmacol. 2016;778:158-68.

39. Finn DF, Walsh JJ. Twenty-first century mast cell stabilizers. Br J Pharmacol 2013;170(1):23-37.

40. Malaviya R, Zhu D, Dibirdik I, Uckun FM. Targeting Janus kinase 3 in mast cells prevents immediate hypersensitivity reactions and anaphylaxis. J Biol Chem. 1999;274(38):27028-38. Erratum in: J Biol Chem 1999 Dec 31;274(53):38276.

41. Jensen BM, Beaven MA, Iwaki S, Metcalfe DD, Gilfillan AM. Concurrent inhibition of kit- and FcepsilonRImediated signaling: coordinated suppression of mast cell activation. J Pharmacol Exp Ther 2008;324(1):128-38.

42. Weston MC, Anderson N, Peachell PT. Effects of phosphodiesterase inhibitors on human lung mast cell and basophil function. Br J Pharmacol 1997;121(2):287-95.

43. Kilinc E, Tore F, Dagistan Y, Bugdayci G. Thymoquinone inhibits neurogenic inflammation underlying migraine through modulation of calcitonin gene-related peptide release and stabilization of meningeal mast cells in glyceryltrinitrate-induced migraine model in rats. Inflammation 2020;43(1):264-273. doi:10.1007/s10753-01901115-w

44. Huang C, Wang Y, Li X, et al. Clinical features of patients infected with 2019 novel coronavirus in Wuhan, China. Lancet. 2020;395(10223):497-506. doi:10.1016/S01406736(20)30183-5

45. Zhang J, Shi GP. Mast cells and metabolic syndrome. Biochim Biophys Acta 2012;1822(1):14-20.

46. Kritas SK, Ronconi G, Caraffa A, Gallenga CE, Ross R, Conti P. Mast cells contribute to coronavirus-induced inflammation: new anti-inflammatory strategy. J Biol Regul Homeost Agents. 2020;34(1):10.23812/20-Editorial-Kritas. doi:10.23812/20-Editorial-Kritas.

47. Conti P, Gallenga CE, Tetè G, et al. How to reduce the likelihood of coronavirus-19 (CoV-19 or SARS-CoV-2) infection and lung inflammation mediated by IL-1. J Biol 
Regul Homeost Agents 2020;34(2):10.23812/EditorialConti-2. doi:10.23812/Editorial-Conti-2

48. Conti P, Ronconi G, Caraffa A, et al. Induction of proinflammatory cytokines (IL-1 and IL-6) and lung inflammation by Coronavirus-19 (COVI-19 or SARS-CoV-2): anti-inflammatory strategies. J Biol Regul Homeost Agents 2020;34(2):1. doi:10.23812/CONTI-E

49. Channappanavar R, Perlman S. Pathogenic human coronavirus infections: causes and consequences of cytokine storm and immunopathology. Semin Immunopathol 2017;39(5):529-539. doi:10.1007/s00281-017-0629-x

50. Fu Y, Cheng Y, Wu Y. Understanding SARS-CoV-2-mediated inflammatory responses: from mechanisms to potential therapeutic tools. Virol Sin 2020;10.1007/s12250020-00207-4. doi:10.1007/s12250-020-00207-4

51. Russell B, Moss C, George G, et al. Associations between immune-suppressive and stimulating drugs and novel COVID-19-a systematic review of current evidence. Ecancermedicalscience 2020;14:1022.

52. Ng PC, Lam CW, Li AM, et al. Inflammatory cytokine profile in children with severe acute respiratory syndrome. Pediatrics 2004;113(1 Pt 1):e7-e14. doi:10.1542/ peds.113.1.e7

53. He L, Ding Y, Zhang Q, et al. Expression of elevated levels of pro-inflammatory cytokines in SARS-CoVinfected ACE2+ cells in SARS patients: relation to the acute lung injury and pathogenesis of SARS. J Pathol 2006;210(3):288-297. doi:10.1002/path.2067

54. Okabayashi T, Kariwa H, Yokota S, et al. Cytokine regulation in SARS coronavirus infection compared to other respiratory virus infections. J Med Virol 2006;78(4):417424. doi:10.1002/jmv.20556

55. Bradding P. Mast cell regulation of airway smooth muscle function in asthma. Eur Respir J 2007;29(5):827-830.
56. Wang J, Wang BJ, Yang JC, et al. Advances in the research of mechanism of pulmonary fibrosis induced by corona virus disease 2019 and the corresponding therapeutic measures. Zhonghua Shao Shang Za Zhi 2020;36(0):E006. doi:10.3760/cma.j.cn501120-20200307-0013

57. Garbuzenko E, Berkman N, Puxeddu I, Kramer M, Nagler A, Levi-Schaffer F. Mast cells induce activation of human lung fibroblasts in vitro. Exp Lung Res 2004; 30:705-721.

58. Batlle M, Perez-Villa F, Lazaro A, et al. Correlation between mast cell density and myocardial fibrosis in congestive heart failure patients. Transplant Proc 2007; 39:2347-2349.

59. Ozbilgin MK, Inan S. The roles of transforming growth factor type beta3 (TGF-beta3) and mast cells in the pathogenesis of scleroderma. Clin Rheumatol 2003; 22:189-195.

60. Andersson CK, Mori M, Bjermer L, Lofdahl CG, Erjefalt JS. Alterations in lung mast cell populations in patients with chronic obstructive pulmonary disease. Am J Respir Crit Care Med 2010;181:206-217.

61. Balzar S, Chu HW, Strand M, Wenzel S. Relationship of small airway chymase-positive mast cells and lung function in severe asthma. Am J Respir Crit Care Med 2005; 171:431-439.

62. Hirata K, Sugama Y, Ikura Y, et al. Enhanced mast cell chymase expression in human idiopathic interstitial pneumonia. Int J Mol Med 2007; 19:565-570.

63. Andersson CK, Andersson-Sjöland A, Mori M, et al. Activated MCTC mast cells infiltrate diseased lung areas in cystic fibrosis and idiopathic pulmonary fibrosis. Respir Res. 2011;12(1):139. 